\title{
In search of a Tropical Gothic in Australian visual arts
}

\author{
Mark Wolff \\ James Cook University, Australia
}

\begin{abstract}
The field of Gothic Studies concentrates almost exclusively on literature, cinema and popular culture. While Gothic themes in the visual arts of the Romantic period are well documented, and there is sporadic discussion about the re-emergence of the Gothic in contemporary visual arts, there is little to be found that addresses the Gothic in northern or tropical Australia. A broad review of largely European visual arts in tropical Australia reveals that Gothic themes and motifs tend to centre on aspects of the landscape. During Australia's early colonial period, the northern landscape is portrayed as a place of uncanny astonishment. An Australian Tropical Gothic re-appears for early modernists as a desolate landscape that embodies a mythology of peril, tragedy and despair. Finally, for a new wave of contemporary artists, including some significant Aboriginal and Torres Strait Islander artists, Gothic motifs emerge to animate tropical landscapes and draw attention to issues of environmental degradation and the dispossession of Australian Aboriginal and Torres Strait Islander peoples.
\end{abstract}

Keywords: tropics, Gothic art, landscape art, Northern Australia. 
7 ropical Australia is a place of extremes. It is the site of appalling and mysterious deaths of famous $19^{\text {th }}$ century explorers, and of cruel and relentless colonial exploitation and murder of Aboriginal and Torres Strait Islander peoples. Covering 40 percent of the Australian continent (CofA, 2015, p. iv), the Australian tropics is also a landscape of vast deserts, sprawling savannahs and grasslands, ancient rainforests and immense coral reef systems. It is a place of prolonged droughts and sudden monsoonal deluges. Months of perfect coastal weather can be followed by the terror of $200 \mathrm{~km}$ per hour cyclonic winds. As this paper will argue, these extremes provide the material for a visual art in which the landscape itself becomes the embodiment of Gothic themes.

\section{Defining Gothic in visual arts}

Before moving to an examination of key artworks and exhibitions that express the Gothic in Australia's tropical north, it is necessary to review how "Gothic" has been defined in the visual arts. The term has a long history. It begins with the Medieval Gothic of the $12^{\text {th }}-16^{\text {th }}$ century in Europe, emerges re-invented as the Romantic Gothic of the late $18^{\text {th }}$ to mid- $19^{\text {th }}$ centuries, and finally re-appears as a set of motifs employed by some modernist and contemporary artists dealing with dark themes.

The Medieval Gothic focused on representing "glorious visions" of biblical stories using some key devices: pointed arches and related ornamental detailing, geometries of nature, and elevated emotions. Beasts, monsters and devils were depicted as fearsome warnings to the faithful, particularly as gargoyles and other grotesqueries in cathedrals. By the mid- $16^{\text {th }}$ century, the Gothic had begun to assume its darker meanings after Giorgio Vasari (1511-1574), the great chronicler of the Italian Renaissance, disparaged the style as created by the "barbarian" Visigoths - Teutonic tribes who had sacked Rome in the $5^{\text {th }}$ century. They had despoiled the great Classical heritage, he said, and "after the manner of their barbarous nations, erected [buildings] in that style which we call Gothic" (Chapuis, 2000, para. 1).

Reacting to industrialisation, classicism and a growing nostalgia for the Medieval past, Romanticism's Gothic revival gave rise to definitive styles of architecture and literature. One strand of visual arts of the Romantic period, influenced particularly by the popularity of the new Gothic literature, sought to entertain and disturb audiences with grotesque visions and sinister mysteries. The leading $19^{\text {th }}$ century British art critic and key promoter of the Gothic revival, John Ruskin (1819-1900), thought Gothic arts ought to be "savage, vital and free...in prickly independence, and frosty fortitude, jutting into 
crockets, and freezing into pinnacles; there starting up into a monster, there germinating into a blossom, anon knitting itself into a branch... or writhed into every form of nervous entanglement" (Connelly, 2015, p. 10).

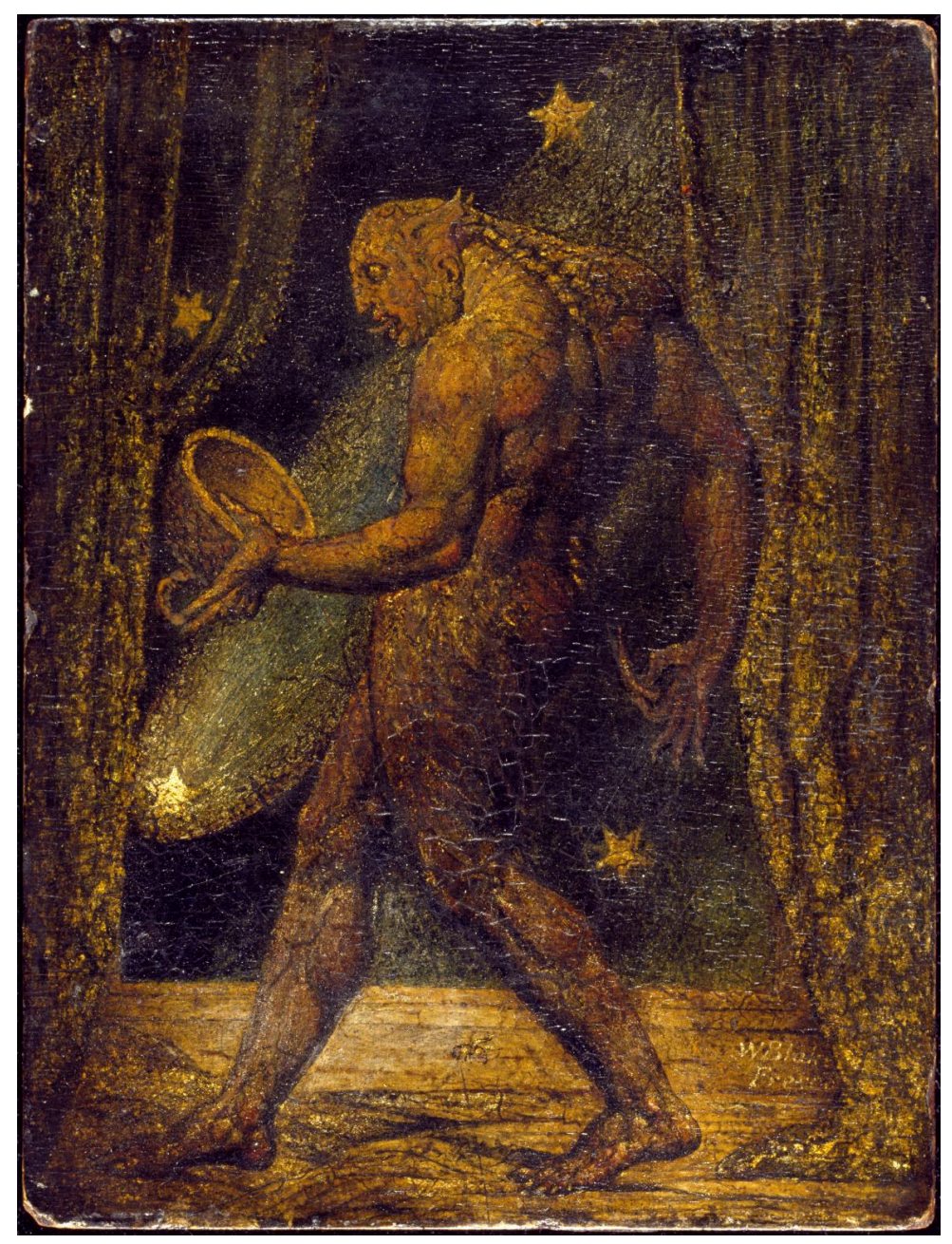

Figure 1. Blake, W. (1819-20). Ghost of a Flea. Tempera and gold on mahogany panel, $21.4 \mathrm{~cm} \times 16.2 \mathrm{~cm}$. (C) Tate. Photo (C) Tate. Licensed under CC-BY-NC 3.0 (Unported).

A contemporary definition of Romantic Gothic art is provided in a landmark 2006 exhibition of iconic Gothic revival artworks at the Tate Britain. The show, Gothic Nightmares: Fuseli, Blake and the Romantic Imagination, featured Ghost of a Flea (c.1819-20) by William Blake (1757-1827), a disturbing "vision" of a tiny, scaly beast drinking blood from an acorn (see Figure 1); and The Nightmare (1781) by Henri Fuseli (1741-1825), which portrays a monkey-like monster perched upon a sleeping woman. In 
their analysis of the exhibition, the curators characterised the Gothic revival in the visual arts as reflecting "[a] taste for fantastic and supernatural themes", which could become apparent in "the shocking and confrontational use of bodily horror", "interest in sex and violence", "sensationalism", "magic, terror and romance", "[sometimes comical] supernatural visions", "fairies and fantasy women", "apocalyptic themes" or "subhuman depravity" ("Gothic Nightmares", 2006).

A century after Romanticism's Gothic revival, Gothic themes and motifs reappear in late $20^{\text {th }}$ century literature, cinema and popular culture, influencing aspects of the visual arts. The Institute of Contemporary Art, Boston, focused on the "new Gothic" in a 1996 exhibition of the works of twenty-three artists from Europe and North America who dealt with fear, horror and dark themes. Titled Gothic: transmutations of horror in late twentieth century art, the exhibition was described by curators as an "engagement with darkness and horror", with the artworks "[drawing] their starting points [from] Gothic music, heavy and death metal, Gothic novels, and horror movies" ("Contemporary Gothic", 1996).

The difficulty involved in arriving at a more complete definition of the Gothic in contemporary visual arts is evidenced through discussion of the 2007 publication, The Gothic, edited by British art critic Gilda Williams and described by publishers MIT as "the first comprehensive survey of the Gothic in contemporary visual culture" ("The Gothic", 2007). Reflecting on the origins of her Gothic project in Art Monthly, Williams is revealing:

I found myself late for a deadline calling for proposals [for an art publisher]. In a panic, I hastily came up with a half-baked idea for a cross-historical art history book titled Gothic Art, and tossed together contemporary artworks by Damien Hirst, Jake and Dinos Chapman and Douglas Gordon with paintings by Francis Bacon, Francisco Goya and Edvard Munch, garnished with a Cindy Sherman dismembered doll, Jeff Wall's Vampire picnic (1991), and Zoe Leonard's Wax Anatomical Model (1990). (Williams, 2009, p.8)

Williams goes on to observe: "This mess was greeted enthusiastically...until someone abruptly asked, 'So what is Gothic? ...[is] Gothic visual art medieval cathedral sculptures and illuminated manuscripts? Or is it Fuseli's Gothic posterchild, The Nightmare?' " (Williams, 2009, p.8). The task of defining the term, according to Williams, is "borderline impossible". Nevertheless, she contends that "contemporary art, on a par 
with film and literature, has...provided a site where the Gothic language or system has been consistently spoken and updated; that is, artists regularly use Gothic tropes in order to address the genre's subject matter - fear, anxiety and death" (Williams, 2009, p. 9). Spooner in her 2006 analysis, Contemporary Gothic, examines the new Gothic largely with reference to literature, cinema and popular culture. In a brief discussion of contemporary visual arts, she suggests that the new Gothic is "defined through subject matter rather than style or historic movement", and provides "a language and a set of discourses by which we can talk about fear and anxiety" (Spooner, 2006, pp. 12, 26-7). Modernist and contemporary artists are unlikely to define their work as following a "Gothic style"; rather, as Spooner and Williams have indicated, they tend to reflect Gothic sensibilities when dealing with dark or disturbing subject matter.

\section{Uncanny Colonial encounters}

The Gothic in northern Australia begins in tropical Queensland with Captain James Cook on his 1770 voyage aboard HMS Endeavour. Cook was full of fear at his encounter with the Great Barrier Reef, where he was "haunted by the thought of the coral labyrinth...the terror of drowning...[and] being marooned in a savage wilderness" (McCalman, 2013, p. 4). One of Cook's artists for the 1770 voyage was Sydney Parkinson (c.1745-1771), who, along with other artists of the early colonial period, provided illustrations of Australian wildlife that were received in the UK with astonishment. George Stubbs (1724-1806) painted the earliest Western image of the kangaroo in 1773 from Parkinson's sketches and a pelt sourced from a kangaroo or wallaby while HMS Endeavour was being repaired in Far North Queensland. From a contemporary perspective, Kongouro from New Holland could not be described as Gothic; however, in its historic context, it would have played into the Gothic taste for the weird and the uncanny.

Gothic themes in European works concerning northern Australia prior to Federation are scarce. Late settlement of Australia's tropical north - almost 100 years after the advent of Romanticism's Gothic revival - coupled with a focus for visual arts on the larger markets of southern Australia, means that an Australian Tropical Gothic, apart from a few colonial examples, was largely absent until its appearance after World War II. The market for art in $19^{\text {th }}$ century northern Australia was almost non-existent. In the south, demand was for landscapes and works of record, "representations of [early settlers] and their property, as well as small scenes of everyday life" (Hackforth-Jones, 1990, p. 272). 


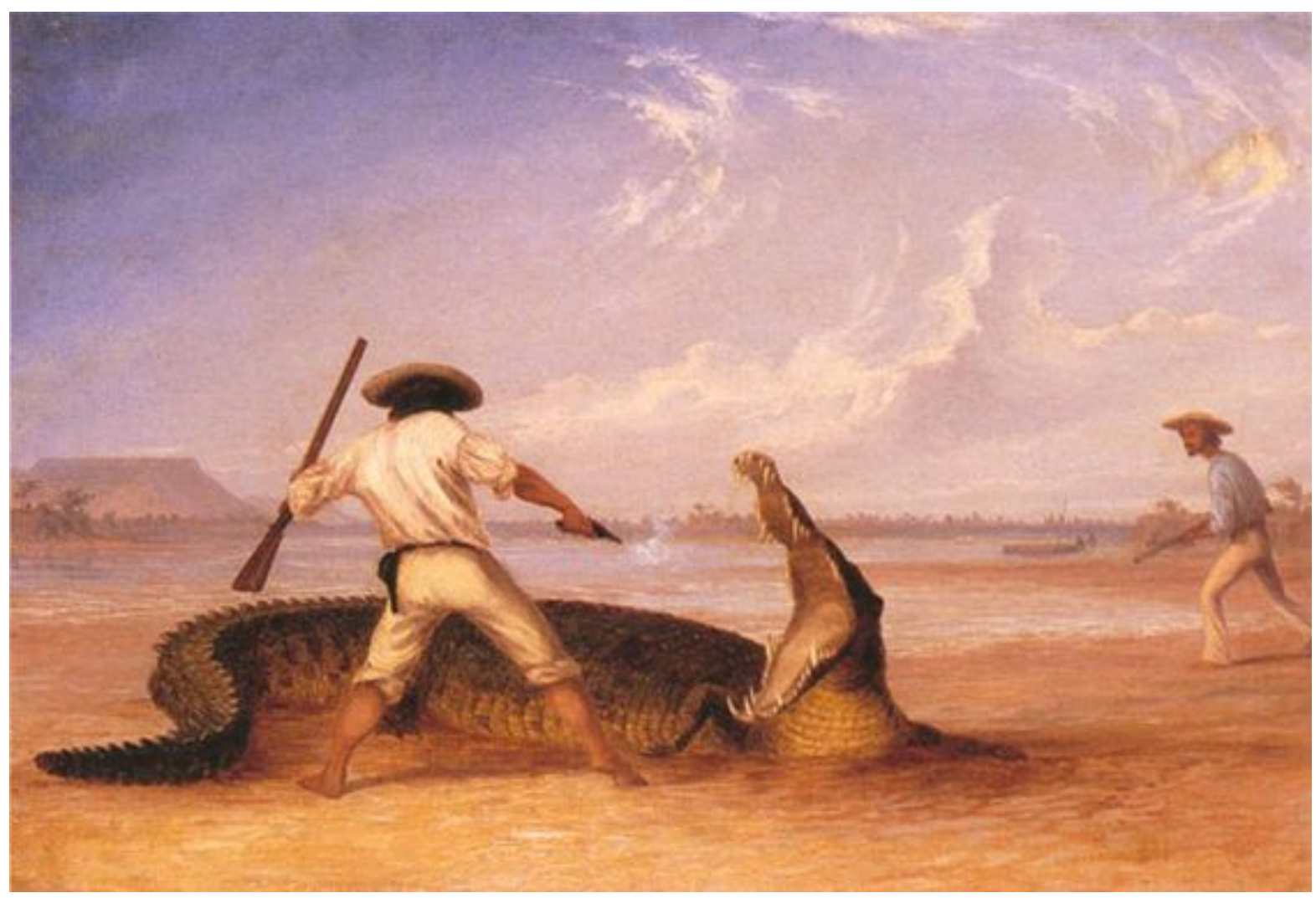

Figure 2. Baines, T. (1856). C. Humphrey and T. Baines killing an alligator on the Horse Shoe Flats near Curiosity Peak, Victoria River. Oil on canvas 45 x $65.8 \mathrm{~cm}$. @ Kerry Stokes Collection, Perth.

A thorough review of colonial artworks associated with northern Australia is beyond the scope of this paper. However, two paintings from the mid- $19^{\text {th }}$ century stand out in their unique reflections of Gothic themes. The first is a depiction of a monstrously large crocodile in the mouth of the Fitzroy River in Australia's tropical Northern Territory. Painted by Thomas Baines (1820-1875), who accompanied A.C. Gregory's North Australia expedition of 1855-56, T. Baines and C. Humphries Killing an Alligator on the Horseshoe Flats near Curiosity Peak, Victoria River (c. 1856) shows the two explorers shooting at a "monster-croc" just as its giant jaws open wide in attack (see Figure 2). The second is a picture of comic terror by Lt Lewis Roper Fitzmaurice (1791-1849). Surveying Party on the North West Coast (1845) shows two European surveyors from HMS Beagle's third voyage "dancing for their lives" while on a cliff above them a crowd of Aboriginal warriors gesticulate and brandish their spears in the dark shadows of a line of gum trees (Fitzmaurice, n.d). The works by Baines and Fitzmaurice portray the anxieties of encountering an unknown land with exaggerated Gothic tropes of foreboding and threat. 


\section{Weird melancholy}

From "discovery" to Federation, Australian visual arts of European origins are dominated first, by the natural history of the early illustrators and "painters of record"; then, by Romantic visions of grandeur and pastoral idealism; and finally, by the selfconsciously nationalistic "Australian impressionism" of the Heidelberg school of the late $19^{\text {th }}$ century.

The sole survey of Australian Gothic art was the 2015 exhibition Weird Melancholy: The Australian Gothic at the Melbourne-based lan Potter Museum of Art. The exhibition revealed what curator Suzette Wearne identified as themes of anxiety, claustrophobia and fear in Australian painting from the $18^{\text {th }}$ century to the present, particularly in relation to depictions of the landscape. The title of the exhibition derived from Australia's best-known Gothic-revival author, Marcus Clarke, who, in an introduction to a collection of Adam Lindsay Gordon's poems, Sea Spray and Smoke Drift, said: "What is the dominant theme of Australian Scenery? That which is the dominant theme of Edgar Allen Poe - Weird Melancholy" (Power, 2013, para. 1).

This exhibition offers much promise for those in search of Australian Tropical Gothic art. However, of the artists represented, only Fred Williams has produced substantial work concerning tropical Australia, none of it redolent of Gothic themes. His early paintings of tropical rainforests are celebratory, and his iconic Pilbara series of the red deserts of north-west Australia, painted a year before his death in 1982, are sublime studies of colour and space.

\section{A darker side to early modernism}

Gothic themes of doom and death under mysterious circumstances in the north of Australia appear with force in the art of two of the nation's early figurative modernists Sidney Nolan (1917-1922) and Albert Tucker (1914-1999). Nolan and Tucker were drawn to the "heroic failures" of early Australian settler history, including the infamous bushranger, Ned Kelly, the doomed explorers Robert Burke and William Wills, and the ill-fated adventurer, Ludwig Leichardt. Nolan concentrated on the story of the 1860-61 Burke and Wills expedition while Tucker focused on the Leichhardt expedition of 1848.

Burke and Wills were appointed by the Royal Society of Victoria to find an inland route for a possible future telegraph line across the Australian continent from Melbourne in the south, to the Gulf of Carpentaria in the north, a distance of some $3250 \mathrm{~km}$. In the 
spirit of Gothic tradition, it is a haunting story of doom. After months of arduous travel by camel and packhorse across deserts and wetlands, Burke and Wills fell just short of reaching the Gulf when their camels were halted knee-deep in a mangrove swamp. They perished in harsh conditions on the way back. Of the four-man party that attempted the final leg of the expedition to the Gulf, only Irish soldier and expedition assistant, John King, survived - with help from local Aboriginal people. King was hailed on his return, with crowds lining the streets of Melbourne yelling: "Here he comes... There is a man who has lived in hell" (Lang, 1895).

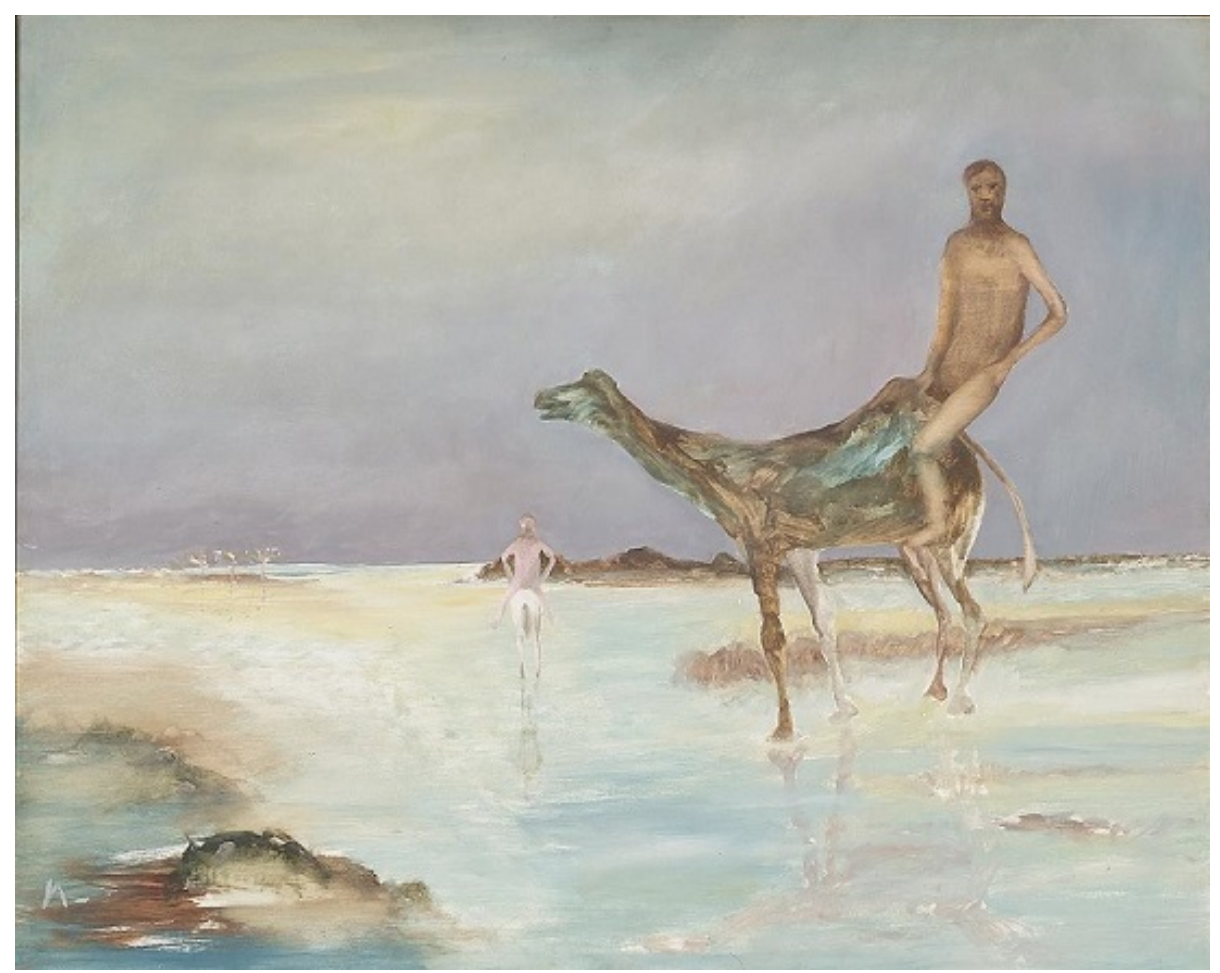

Figure 3. Sidney Nolan, S. (1961). Burke and Wills at the Gulf. Synthetic polymer on hardboard. $122.2 \times 152.6 \mathrm{~cm}$. National Gallery of Victoria, Melbourne/Bridgeman Images.

(c) The Trustees of the Sidney Nolan Trust/Bridgeman Images.

While Nolan's early portrayals of Burke and Wills in the arid north, such as Burke and Wills expedition (1948), show the explorers amidst the harsh, arid landscape confidently looking at the viewer, his return to the subject in the 1960s is explicitly haunting. According to art historian and curator Sarah Engledow, in works like Burke and Wills at the Gulf (1961) "man and camel became fused in the seamless treatment of their construction (see Figure 3). The figures are apparitions, ghost-like in a landscape of mirages - man and nature finding themselves together at the Gulf of Carpentaria in a place where water and earth meet in a shifting, indivisible mix" (Engledow, 2009). The 
Burke and Wills series is part of a key transformation in Nolan's Australian art - a shift from depiction to narrative that employs "the landscape [as] the theatre for human drama" (Capon, 2018). It is a narrative that goes beyond the heroic outsider pitted against harsh conditions, into the spectre of death under an apocalyptic tropical heat. The Gothic trope of terror as imminent annihilation by powerful and mysterious forces, is situated within the landscape itself.

A similar dread is evoked by Albert Tucker's 1959 painting, Death of Leichhardt (see Figure 4). Mixing sand with his paint, Tucker creates an unnerving view of the skeletal remains of $19^{\text {th }}$ century German explorer, Ludwig Leichhardt, sinking into the red-ochre ground of arid northern Australia, surrounded by abstracted motifs of gaunt, lifeless trees. Leichhardt and his party of six had attempted to cross the Australian continent in 1848 from the East (Darling Downs) to the West (Swan River), most likely via a northern arc that took them into tropical Australia. All members of the expedition perished, and the location of their remains is one of the enduring mysteries of European exploration (Erdos, 1967). In 1901, a brass nameplate inscribed "Ludwig Leichhardt 1848" was found at Sturt Creek, near the Great Sandy Desert in the north-west of Australia apparently confirming Leichhardt's death in the tropical north (Lagan, 2013, para. 14).

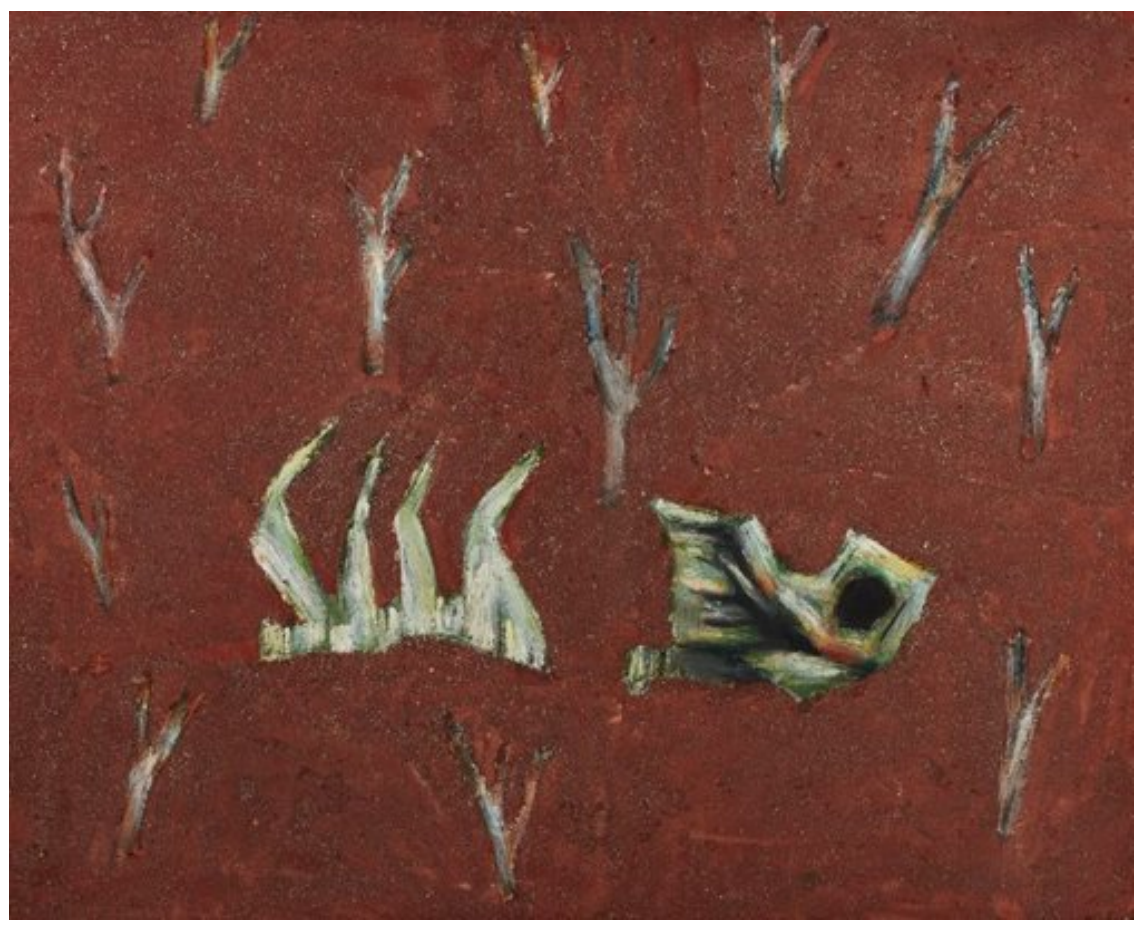

Figure 4. Tucker, A. (1959). Death of Leichhardt. Polyvinyl acetate and sand on hardboard, $122 \times 153 \mathrm{~cm}$. Art Gallery of NSW, Sydney. (C) Albert \& Barbara Tucker Foundation. Courtesy of Sotheby's Australia. 
Death of Leichhardt forms part of a thematic series of works on explorers and early settlers that preoccupied Tucker from the late 1950s. For some of his key works on early settlers, he developed an angular, double-axe shaped "Antipodean Head" that he positioned in the foreground against desolate landscape backgrounds. These gaunt, scored heads are presented as tormented and monstrous Gothic figures, confronting a harshness from which there is no escape. In their grotesque form they can be seen as a modernist revision of the Romantic Gothic monster. They are "an intrusive white presence, [who] perish by virtue of their ignorance and relentless drive" (Burke, 2002, p. 353). Tucker's disturbing explorer and "intruder" paintings include works such as Explorers: Burke and Wills (1960), Intruder resting (1965-66), the grotesque Antipodean Head II (1959) and Intruder and Parrots (1964-68) in which rainbow parrots attack an Antipodean head, with tropical Pandanus trees - many stripped of their foliage silhouetted in the background (see Figure 5). An early environmentalist, Tucker employed the theme of the intruder to comment on the destruction modernity was visiting upon the landscape. According to his biographer, Janine Burke, Tucker himself was "a Gothic character... painting the darker side, the depths" (Burke, 2002, p. xv).

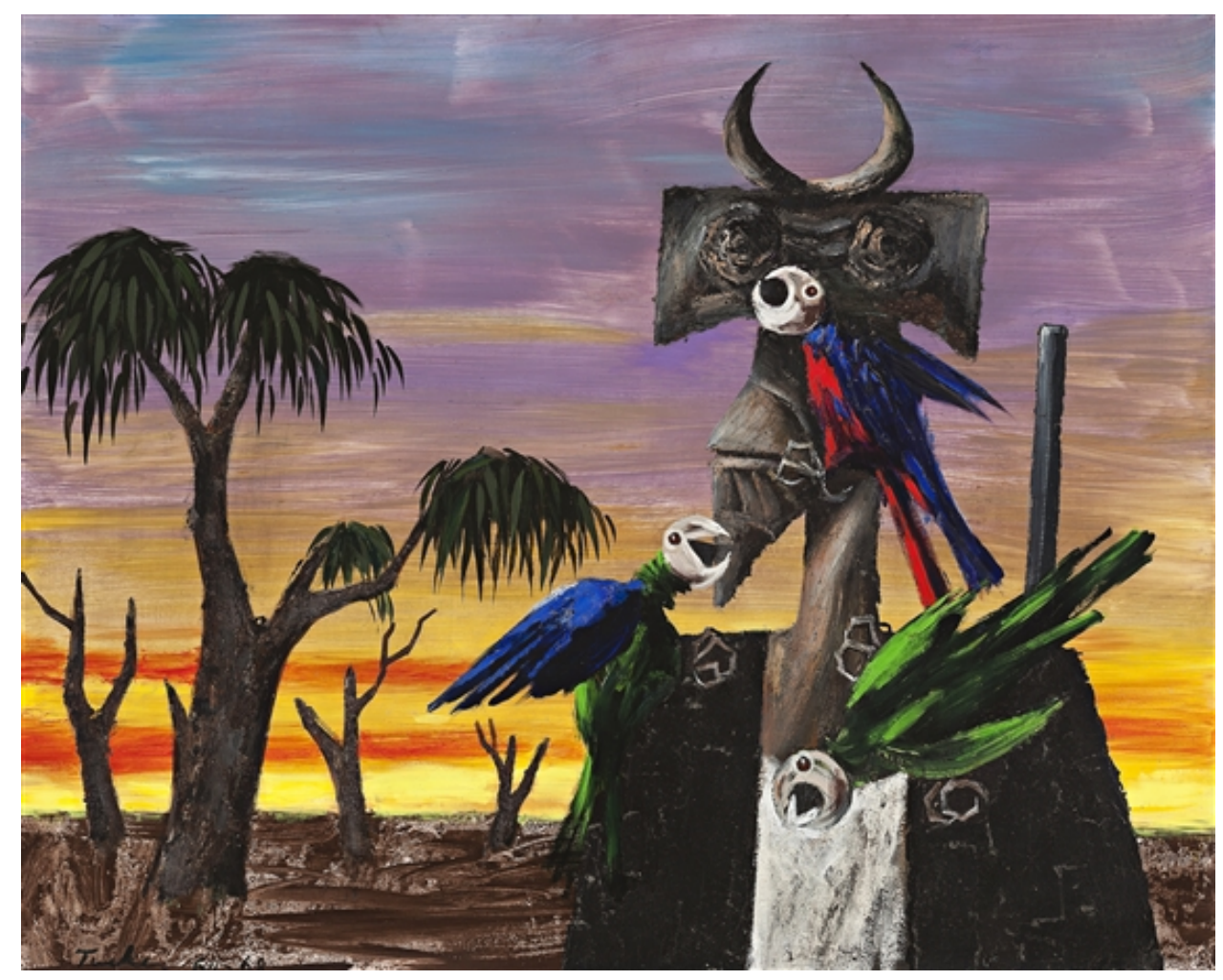

Figure 5. Tucker, A. (1964-68). Intruder and Parrots. Synthetic polymer paint on composition board, 122 x $152 \mathrm{~cm}$. (C) Albert \& Barbara Tucker Foundation. Courtesy of Sotheby's Australia. 
The outlying settlements of the arid regions of the Australian north are perhaps most eerily depicted in the works of Russell Drysdale (1912-1981), who travelled to tropical Queensland in the 1950s and again in the 1960s. Saddling up at the races, Coen (1953) shows a group of Aboriginal men getting a gaunt racehorse ready for an outback race. The earth is red, and the sky a threatening crepuscular blue. There is an oppressive melancholy, a haunting stillness, that reveals Drysdale's concern for the welfare of Aboriginal peoples and management of the environment (Parker, 2013, paras $9 \& 13$ )). In 1965, after Drysdale's son and first wife committed suicide, he travelled again to the northern tropics (Maslen, 2003, para. 4). As a result of this trip he painted one of his most iconic works, The Outstation (1965), in which a lone Aboriginal stockman poses under the shaded eave of a corrugated iron shed (see Figure 6). In the distance, where the stark, orange-ochre earth begins to merge into the sky, stand the outstation's apparently deserted sheds. The stockman's stance is melancholy, but self-possessed, his direct stare hidden by the shade of his bush hat. It is a picture of desolation, loss and dispossession.

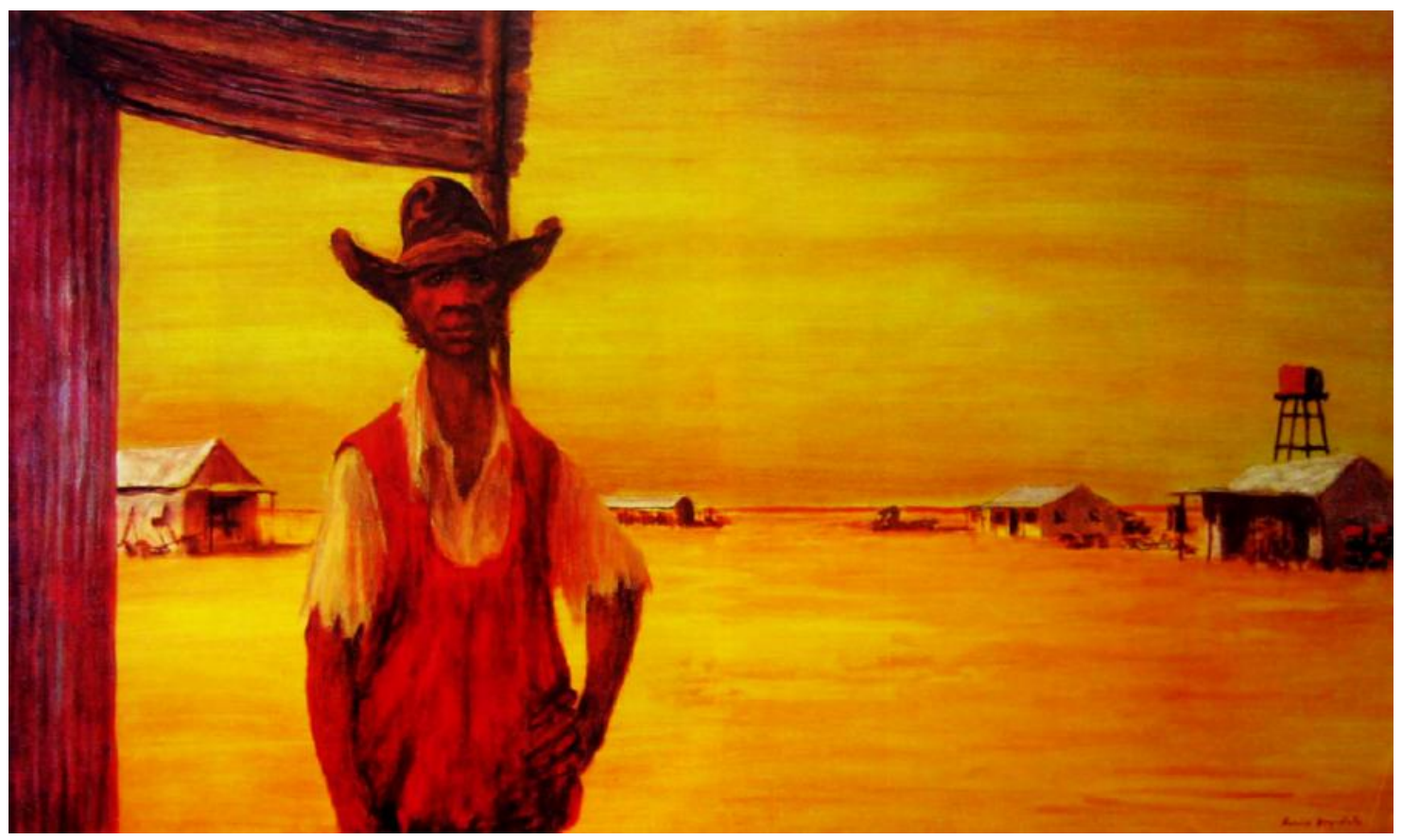

Figure 6. Drysdale, G. R. (1965). The Outstation. Oil on canvas, $76.5 \times 127 \mathrm{~cm}$. Private Collection. (C) The Estate of Russell Drysdale.

Nolan, Tucker and Drysdale each portray a landscape infused with Gothic themes. For these artists, tropical Australia is a site of a desolate melancholy, grotesquery, intrusion, haunting mystery, unforgiving nature, and death. As Kelly has observed while analysing 
Australian landscape art in general, "postcolonial landscape may also be seen as a ruin where elements of Australian gothic sensibility characterised by desolation, secrecy and isolation, create a disconsolate space" (2018, p. 202).

\section{Contemporary anxieties}

Since the 1970s there has been a re-emergence of Gothic themes in literature, cinema and popular culture in tropical Australia (Blackwood, 2018; Craven 2008; Philp, 2017; Spicer 2016a \& 2016b). Many contemporary Australian visual artists have also engaged with Gothic subject matter, including Susan Norrie, Rodney Pople, Ken Unsworth, Peter Booth, Bill Henson, Rosemary Liang, Simryn Gill, Leah King-Smith, Jane Burton, Joel Zika, Dale Frank and Stelarc. None of these visual artists, however, have focused substantially on northern Australia.

The 2014 Adelaide Biennale, Dark Heart, curated by Nick Mitzevitch, sought to capture a changed Australian zeitgeist that reviewer Joanna Mendelssohn has called a "dark night of the national soul" and a "terrible pragmatism of cruelty" (Mendelssohn, 2014, para. 2). The Biennale addressed questions of national identity, with many works employing Gothic themes to engage viewers. The exhibition included photographs of the grim and deserted landscapes of British nuclear test sites in Central Australia by Rosemary Liang, a wooden cuckoo clock painted with a skull shape by Fiona Hall, and The Island, a major work by Ben Quilty, which "quotes" part of a colonial representation of the Gordon River in Tasmania, and aims to draw attention to threats to the Australian environment. Lynette Wallworth produced an installation of song, sound, painting and moving image in collaboration with Martu artists from the Pilbara in the far north-west of Australia, which explores Aboriginal understandings of the land. Alex Seton's installation, Someone died trying to have a life like mine, was the only work dealing with the north that reflected a Gothic sensibility. The installation consisted of 28 carved marble lifejackets, some laid out on the gallery floor in groups like family units. The artwork refers to an incident in May 2013 when 28 lifejackets washed ashore on the Cocos Islands off Western Australia's northern coast. While no bodies were found, authorities assumed that the lifejackets belonged to refugees who had perished at sea trying to reach Australia (ABC, 2013). Marble is often reserved to memorialise prominent figures, and the use of such a valuable material to sculpt lifejackets is simultaneously a symbolic elevation of the status of unknown refugees, and a haunting Gothic reference to the missing, presumed dead. Seton's installation, although not specifically about tropical Australia, reminds us that the waters surrounding the nation's north can be sites of violent exclusion. 
The disturbing nature of the Gothic enables it to function as a form that is "well placed to capture [environmental] anxieties and [provide] a culturally significant point of contact between literary criticism, eco-critical theory and political process" (Gonder, 2014). A key environmental issue addressed by contemporary artists concerned with northern Australia is the vulnerability of the Great Barrier Reef. For these artists, coral bleaching provides a poignant, ghostly symbol that reflects a liminal state between life and death a central trope of many Gothic narratives. The "white ghost" motif is used by Cairnsbased artist, Robyn Glade-Wright, in her Exodus (2014), a sculpture of an eight-metre "canoe" of bleached coral forms. Glade-Wright's strategy is to utilise the seductive power of beauty to trigger anxiety about the future of the Reef (Glade-Wright, 2016). Sydney-based artist, Janet Laurence, collaborates with environmental scientists to tackle threats to the Great Barrier Reef in her installation, Deep Breathing, Resuscitation for the Reef (2015). The installation uses transparent panels and laboratory flasks, jars and containers, mirrors and specimens drawn from scientific collections to create a disturbing picture of an ecosystem balanced between destruction and rescue. Medical tubing is threaded between containers, linking, for example, preserved specimens of endangered fish to a skeletal sea sponge and bleached coral (Gibson, 2016). The dominant colour is a ghostly white.

The critical environmental issue of species extinction is the subject of Fiona Hall's Kuka Irititja (2015), which translates as "animals from another time" (Carrigan, 2015, para. 4). Exhibited as part of her 2015 Venice Biennale installation, these works are the result of Hall's collaboration with twelve Aboriginal women artists, the Tjampi Desert Weavers of the Ngaanyatjarra Pitjantjatjara Yankunytjatjara (NPY) lands, which are located at the northern border of South Australia and extend through to tropical Australia. Kuka Irititja presents figures of endangered and extinct fauna woven from wild-harvested grasses and other materials, and placed on charred books. They are distressing resurrections of the dead or dying - ghosts come to haunt the viewer.

Rising concern about environmental degradation in tropical Australia is also evident in an exhibition held at the Mayfair Gallery in the Northern Territory as part of the 2018 Darwin Festival. Tropical Gothic: A Selection of Dark Works for Warm Climes featured artworks by emerging Northern Territory artists Marita Albers, Sandra Kendell, Sonia Martignon and Nat Quintos Uhing, and was billed as a "curio case of tropical twilights, beast and beauties, with expeditions to the recesses of monsoon forests, psychic shadows and salty shipwrecks" (Darwin Festival, 2018). 


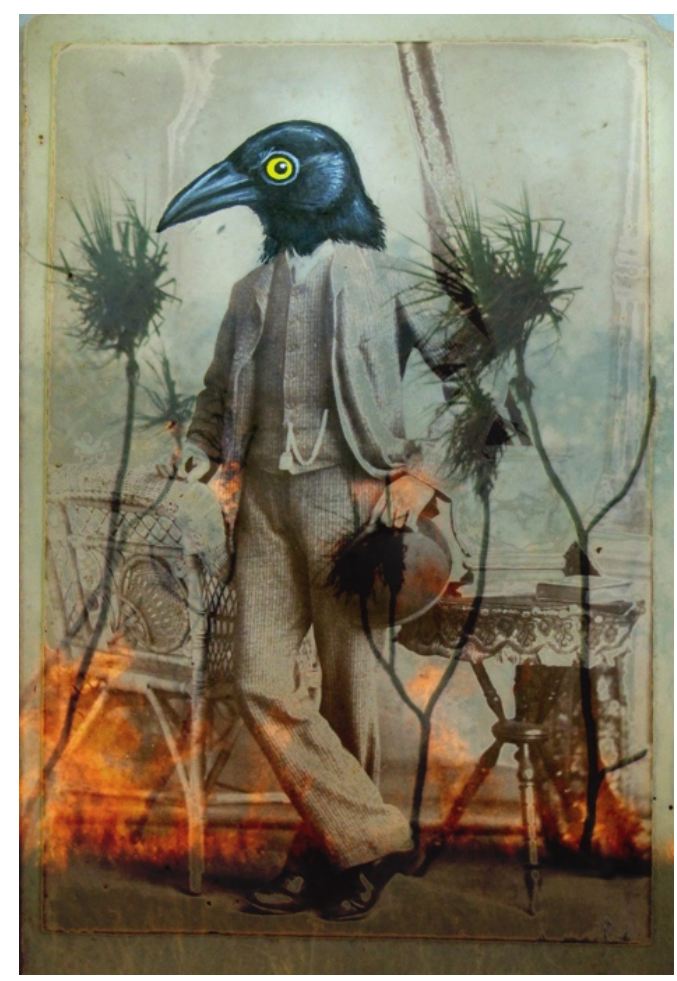

Figure 7. Kendell, S. 2018. Mr Crow of Stuart Park. Digital print, 26 x 18cm. @ The artist.

Kendell and Martignon used hybrid beasts conjoining bird heads to human bodies to highlight colonial alienation from tropical nature, and promote the need for stronger environmental protection. Kendell's digital artworks were based on $19^{\text {th }}$ century portraits (see Figure 7), and were designed to "reference...the feeling of unease within the tropical landscape experienced by colonial European settlers" (Kendell, personal communication, February 7,2019 ). In turn, Martignon presented a pantheistic take on the reverential aspects of the Medieval Gothic with "tropical trees with their strong buttress roots, sweeping branches and mythological Nymphs protecting the...natural world" in her carved and painted wood panels (Martignon, personal communication February 7, 2019). Martignon's nymphs are humans with pelican heads, acting as guardian "nature spirits"; her protective fig tree roots are reminiscent of the flying buttresses of Gothic cathedrals.

\section{Burning cane and shadows in the rainforest}

No discussion of the art of northern Australia can take place without acknowledgement of the cultural significance of the visual arts of Aboriginal and Torres Strait Islander peoples of the north, who make up some 30 percent of the Indigenous population of 
Australia (CofA, p.111). Their art is complex and vast. There is reliable evidence of rock art in northern Australia dating back to 28,000 BP from the rock shelter, Nawarla Gabarnmang, in Arnhem Land in the Northern Territory (David et al, 2013, pp. 3-10), and it is possible that Aboriginal and Torres Strait Islander art traditions extend back 65,000 years, based on analysis of ground ochres found in new excavations at Madjedbebe, another rock shelter in Arnhem Land (Clarkson et al., 2017, p. 309). There are over 200 discrete communities across the tropical north (CofA, 2015, p. 112), many with their own visual arts traditions, and evolving practices. There are also significant Aboriginal and Torres Strait Islander artists who engage directly with Western art traditions, some of whom work from national and international urban arts centres.

The Gothic is a Eurocentric concept, and approaching Aboriginal and Torres Strait Islander arts through a "Gothic lens" must take account of context. There are "monster" spirits represented in some mythological traditions, such as the malevolent Mamu, of the Anangu people of central Australia, who can enter a person's body and steal their soul; or the Jarnpa spirits of the Warlpiri people of the Northern Territory, invisible flying beings who steal, rape and kill. These are not metaphorical figures, and resist a European Gothic interpretation. As Musharbash states in her introduction to Monster Anthropology in Australasia and Beyond, "The monsters that anthropologists encounter in their field-sites prowl the real world, not across the pages of books or on television and cinema screens (Musharbash \& Pesterudstuen, 2014, p.52).

Acclaimed Aboriginal artists, Rover Thomas (c.1926-1998) and Queenie McKenzie (1915-1998) from the Kimberley region in remote north-western Australia, depicted the frontier massacres of their people that occurred from the 1880s to the 1930s in works that were acquired by the Australian War Memorial in 2017. Thomas's Ruby Plains Massacre 1 (1985) includes a symbol of a decapitated head in a tree hollow as part of a seemingly abstracted depiction of Ruby plains - a rare figurative element in his oeuvre. The station owner at Ruby Pains had "shot dead several Aboriginal men in retaliation for the killing of a bullock. Some days later, Aboriginal stockmen were drawn to the killing site by crows circling above and found the decapitated heads of the men in a hollow tree trunk" (Australian War Memorial, 2017). While the skull symbol is often used as a Gothic motif; perhaps in this context, it is simply historically accurate.

Two Australian Indigenous artists who engage directly with the Western arts tradition and exemplify a contemporary Gothic sensibility in some of their artworks are Tracey Moffatt, a filmmaker and photographer who represented Australia at the 2017 Venice Biennale, and Danie Mellor, who won the 2009 Telstra National Indigenous Art Award. 
Mellor, who traces his Indigenous heritage to the tropical rainforests of the Atherton Tablelands in tropical Queensland, examines the dark histories of Aboriginal peoples of the Wet Tropics (see Figure 8). In his exhibition, Exotic Lies, Sacred Ties (2014), Mellor portrayed complex jungles often inhabited by sometimes ghostly images of Aboriginal rainforest peoples and native fauna (Eccles, 2015, pp. 31-35). His uncanny and complex representations of the tangled forest, and his occasional use of skull and ghost-like imagery, reflect some key Gothic motifs, creating a melancholic testament to a lost "arcadia". According to Mellor, "There is a continual dialogue in [the] work between the seen and unseen, the material and immaterial" which is achieved within the landscape with "an obsessive focus on detail and the minutiae of nature" (Mellor, 2014. p. 14).

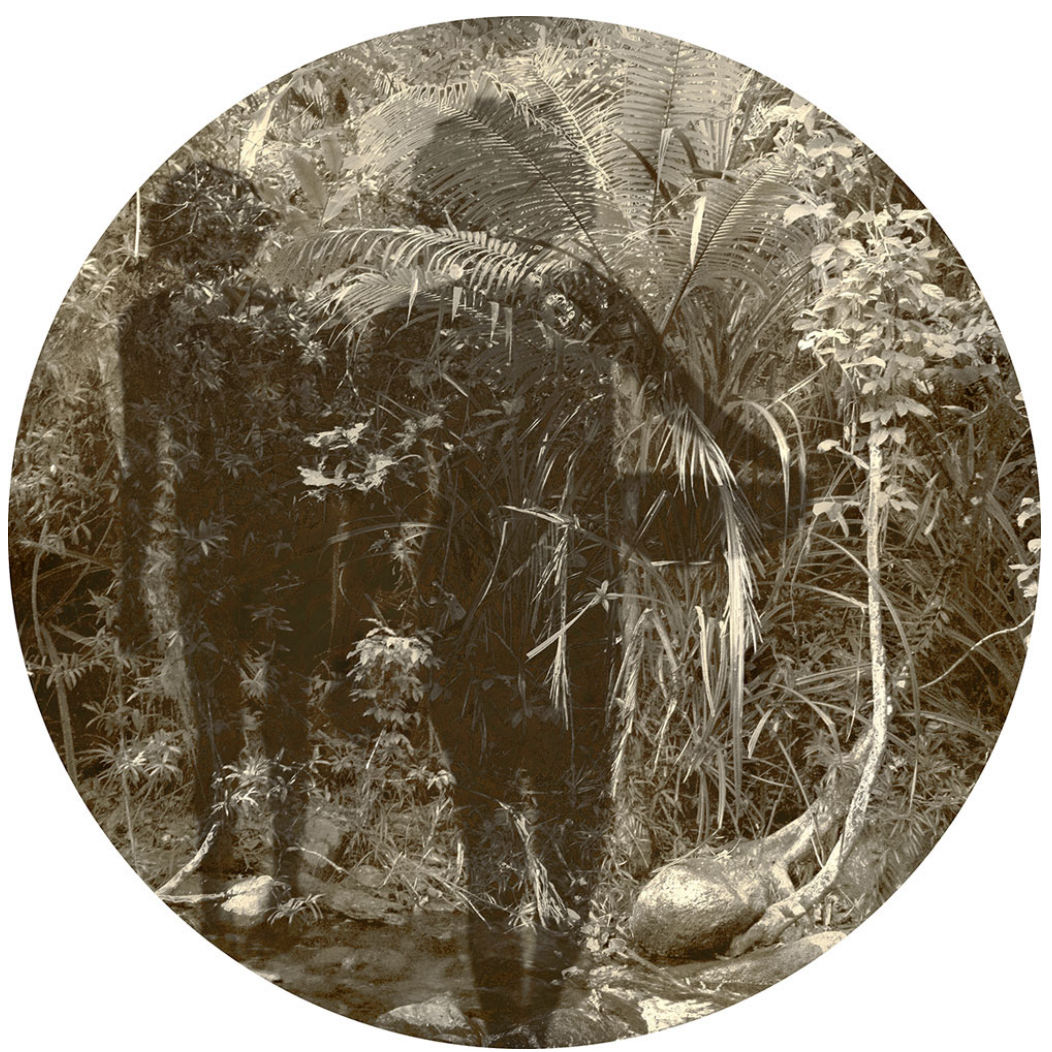

Figure 8. Mellor, D. (2018). Natura Pacifica (bulan mulgal). Lambda print on metallic photographic paper, 90 x $90 \mathrm{~cm}$. (c) the Artist and Tolarno Galleries.

While Mellor's work represents a melancholic portrayal of loss and dispossession, some of Tracey Moffatt's artworks are explicitly ominous and threatening. Moffatt often uses narrative tableaux in her photographic works to explore alienation and pain, the unseen and the disturbing, in relation to Aboriginal and Torres Strait Islander histories. Some of 
her work borrows heavily from Gothic themes, including horror stories, nightmares and the "underworld". Sydney's Museum of Contemporary Art described her Invocations (2000) series as "peopled by witches and spirits, the lost and vulnerable, who stumble through scenes and landscapes summoned from Disney's animations, Hitchcock's movies, Goya's paintings and the stories of the Brothers Grimm" (MCA, 2013). Moffatt says Invocations is about "the dark underworld that we all have... it's about the murk in all of us" (James, 2001, para. 2).

Moffatt's 2016 show at the Art Gallery of New South Wales, Laudanum and other stories, presented a photographic series that employs the aesthetic of $19^{\text {th }}$ century photography to evoke a disturbing past. The exhibition included the 13-diptych series, Plantation, which situates the coastal tropics of northern Queensland as the location for unsettling colonial narratives (see Figure 9). There is a ramshackle old "Queenslander" house with a verandah and an overgrown tropical garden, burning cane fields and a silhouette of a partly hidden, dark-skinned man. The effect is morbid and menacing, referencing the exploitation of Australian Indigenous and Pacific Islander "sugar slaves" who were indentured and sometimes kidnapped to work in the Queensland sugar industry. Like Rachel Perkins' film, Radiance (1993), an old Queenslander house on a cane farm functions as an Australian version of a Gothic ruin, a location for nightmarish scenes (Craven, 2016, p. 49), while the burning sugar cane presents the opposite of a tropical paradise - a dystopian "anti-Eden".
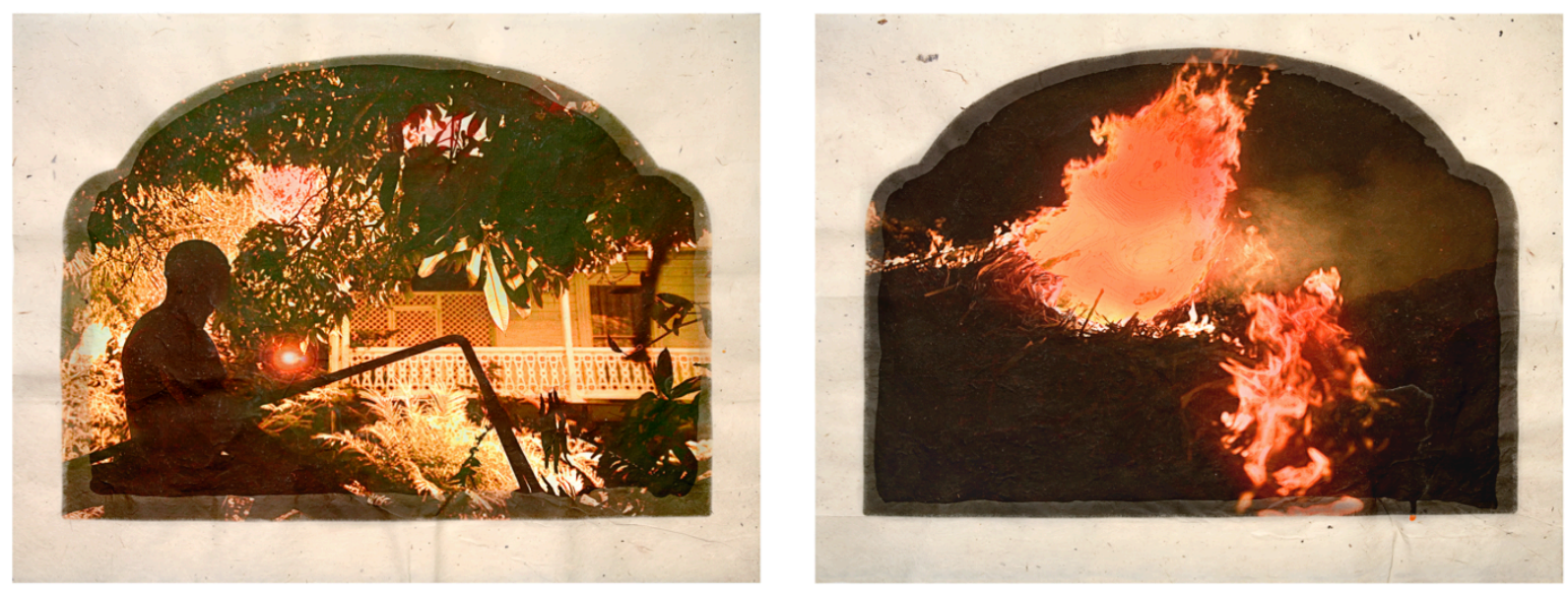

Figure 9. Moffatt, T. (2009). Plantation (Diptych No. 10). Digital print with archival pigments, InkAid, watercolor paint and archival glue on handmade Chautara Lokta paper, $46 \times 50.5 \mathrm{~cm}$ (each).

(c) Roslyn Oxley9 Gallery and the Artist, Sydney. 
Art critic Julie Ewington, reviewing the show for The Monthly, observed: "The burning cane fields and the powerful shadowy man watching from the margins suggest Mandingo as much as Mackay, and this is purposeful: as a teenager in the 1970s, Moffatt read the Southern Gothic novelists, including William Faulkner and Eudora Welty" (Ewington, 2016, para. 3). Plantation is a chilling Contemporary Gothic critique of the slavery-powered sugar industry that thrived across the tropical world in the $19^{\text {th }}$ century. Moffatt uses this disturbing past to raise dark issues of identity, fear and desire. Again, these anxieties are played out in the landscape - fields of fire, and threatening shadows beneath fecund tropical foliage.

\section{Disturbing nature}

Australia's Tropical Gothic begins as an "art of record" of uncanny images of strange forms of wildlife, or of shadowy menace from Aboriginal and Torres Strait Islander peoples. These are weird images, intended for the amazement - and amusement - of a European audience. They offer a disturbing, perhaps uncanny, perspective of nature to viewers struggling to incorporate other cultures and ecologies into their knowledge and belief systems. Apart from these uncanny images of explorations of the north, the Romantic Gothic revival largely bypasses the visual arts in tropical Australia.

The Gothic re-emerges in the mid- $20^{\text {th }}$ century as a mythologising project of early figurative modernists dealing with the failed explorers and early settlers of northern Australia. Tucker and Nolan portray an unforgiving environment in which figures either disappear into the landscape's vast heat, or are attacked by wildlife. It is not the explorers or settlers who are pictured, but their failed relationships with the environment - as if the land was seeking revenge for transgression. Drysdale takes a different tack. He depicts lonely individuals or desultory groups - sometimes Aboriginal - within a surreal, all-encompassing space to achieve an effect of deep and foreboding melancholy. Again, it is the landscape that dominates - with sinister undertones.

Finally, Gothic themes and motifs reappear in contemporary arts as part of an artistic strategy to examine environmental and postcolonial anxieties and concerns in northern Australia. Once more, it is nature that takes centre stage, whether it is the Great Barrier Reef under threat, the rainforest and its dispossessed Aboriginal peoples, the exploitations of the colonial sugar industry, or concerns about extinct or endangered wildlife.

The search for a Tropical Gothic in Australian visual arts reveals a consistent 
engagement with the natural environment. There is no interior here. No ruined churches or castles; no haunted houses. Where "monsters" or ghost-like figures are portrayed, it is as an integral part of the land. For visual artists dealing with disturbing themes in northern Australia, it is the landscape itself that serves as a Gothic motif, embodying contemporary anxieties and troubled pasts.

\section{References}

ABC. (2013). Fears for asylum seekers after life jackets wash up on Cocos Island beach. $A B C$ News. Retrieved from https://www.abc.net.au/news/2013-05-27/fears-more-asylumseekers-may-have-drowned/4714346

Australian War Memorial. (2017). Ruby Plains Massacre 1. Retrieved from https://www.awm.gov.au/collection/C2148046?search

Blackwood, G. (2018). Tropical Darwin on screen: Critiquing national values using urban frontier Tropes in Charlie's Country and Last Cab to Darwin. eTropic, 17 (2), 132-150.

DOI: http://dx.doi.org/10.25120/etropic.17.2.2018.3661 Retrieved from https://journals.jcu.edu.au/etropic/article/view/3661/17.2.11.1

Burke, J. (2002). Australian Gothic: A life of Albert Tucker. Sydney: Random House.

Capon, E. (2018). Quoted in Sally Aitken (Director), Nolan. Sydney: ABC TV.

Carrigan, J. (2015). Australian politics at the Venice Biennale. The New York Times, May 7.

Retrieved from https://www.nytimes.com/2015/05/07/arts/international/australian-politics-atthe-venice-biennale.html

Chapuis, J. (2000). Gothic Art. Heilbrunn Timeline of Art History. New York, NY: The Metropolitan Museum of Art. Retrieved from http://www.metmuseum.org/toah/hd/mhot/hd mgot.htm

Clarkson, C., Jacobs, Z., Marwick, B., Fullagar, R., Wallis, L., Smith, M., ... Pardoe, C. (2017). Human occupation of northern Australia by 65,000 years ago. Nature, 547(7663), 306-310. DOI:10.1038/nature22968 Retrieved from https://www.nature.com/articles/nature22968

Commonwealth of Australia. (2015). Our north, our future: White Paper on developing northern Australia. Canberra: Commonwealth of Australia.

Connelly, F. (2015). John Ruskin and the savage gothic. Journal of Art Historiography, 12, 1-16. Retrieved from https://arthistoriography.files.wordpress.com/2015/06/connelly.pdf

"Contemporary Gothic". (n.d.). Artsy. Retrieved from https://www.artsy.net/gene/contemporarygothic

Craven, A. (2008). Tropical Gothic: Radiance revisited. eTropic, 7, 1-15. DOI: http://dx.doi.org/10.25120/etropic.7.0.2008.3431 Retrieved from https://journals.jcu.edu.au/etropic/article/view/3431/3369

Craven, A. (2016). Finding Queensland in Australian cinema. New York, NY: Anthem Press.

Darwin Festival. (2018). Contemporary Gothic: Presented by Mayfair Gallery. Retrieved from https://2018.darwinfestival.org.au/events/tropical-gothic

David, B., Geneste, J., Petchey, F., Delannoy. J., Barker, B., \& Eccleston, M. (2013). How old are Australia's pictographs? A review of rock art dating. Journal of Archaeological Science, 40 (1), 3-10. https://doi.org/10.1016/j.jas.2012.08.019 Retrieved from https://www.sciencedirect.com/science/article/pii/S0305440312003706 
Eccles, J. (2015). Danie Mellor. Eyeline, 81. Retrieved from https://www.eyelinepublishing.com/eyeline-81/article/danie-mellor

Editors. (2018). Tracey Moffatt. Arts Review, May 18. Retrieved from https://artsreview.com.au/tracey-moffatt-laudanum-and-other-works/

Engledow, S. (2008-09). Through blue eyes, Portrait, 30, (Summer). Retrieved from https://www.portrait.gov.au/magazines/30/through-blue-eyes

Erdos, R. (n.d.). Friedrich Wilhelm Ludwig (1813-1848), Australian dictionary of biography. Retrieved from http://adb.anu.edu.au/biography/leichhardt-friedrich-wilhelm-ludwig-2347

Ewington, J. (2016). Tracey Moffat's Laudanum and other works. The Monthly, July. Retrieved from https://www.themonthly.com.au/issue/2016/july/1467295200/julie-ewington/traceymoffatt-s-laudanum-and-other-works

Fitzmaurice, C. (n.d.). Lewis Roper Fitzmaurice (29 Apr 1816 - 22 Apr 1893). Retrieved from http://fitzmaurice-family.com/LRF.html

Gibson, P. (2016). Here's looking at: Deep breathing: Resuscitation for the reef by Janet Laurance. The Conversation, August 29. Retrieved from_https://theconversation.com/hereslooking-at-deep-breathing-resuscitation-for-the-reef-by-janet-laurence-63408

Glade-Wright, R. (2016). Uncertain futures: Coral bleaching and the loss of innocence, beauty and the sublime. eTropic, 15 (1), 39- 49.

DOI: http://dx.doi.org/10.25120/etropic.15.1.2016.3299. Retrieved from https://journals.jcu.edu.au/etropic/article/view/3299/3244

Gonder, P. (2014). Ecogothic. [Review of the book Ecogothic, by Andrew Smith \& William Hughes (Eds), Manchester: Manchester UP, 2013]. ISLE: Interdisciplinary Studies in Literature and Environment, 21 (3), 716-717. https://doi.org/10.1093/isle/isu118 Retrieved from https://academic.oup.com/isle/articleabstract/21/3/716/773563?redirectedFrom=fulltext

"Gothic Nightmares". (2006). Gothic nightmares: Fuseli, Blake and the Romantic imagination: 15 February - 1 May 2006. Tate Britain: London: UK. Retrieved from https://www.tate.org.uk/whats-on/tate-britain/exhibition/gothic-nightmares-fuseli-blake-andromantic-imagination

Hackforth-Jones, J. (1990). Review of the book, The Colonial Image: Australian Painting 18001880 by Tim Bonyhady. Journal of Historical Geography, 16 (2), 272-273. Retrieved from https://www.sciencedirect.com/science/article/pii/030574889090122R

James, B. (2001). Interview with Trace Moffatt, ABC Arts, January 9. In Tracey Moffatt: Invocations \#1, 2000. Sydney, NSW: Museum of Contemporary Art. Retrieved from https://www.mca.com.au/artists-works/works/2013.70.1/

Kelly, C. (2018). Colonial and gothic dissonance: Tracing desire lines through postcolonical landscape [Abstract]. In Prowse, N. (ed.), Intervening spaces. Respatialisation and the body (202-219). Leiden: Koninklijke Brill NV. https://doi.org/10.1163/9789004365520_012 Abstract retrieved from https://brill.com/view/book/edcoll/9789004365520/BP000014.xml

Lagan, B. (2013). What really happened to Ludwig Leichhardt, The Guardian, May 31. Retrieved from https://www.theguardian.com/science/2013/may/31/what-really-happenedludwig-leichhardt

Lang, A. (ed.). (1895). The Red True Story Book. Retrieved from http://www.burkeandwills.net.au/Brief_History/red_true_story_book_lang.htm

Maslen. G. (2003). Drysdale dreaming. The Age, April 29. Retrieved from https://www.theage.com.au/entertainment/art-and-design/drysdale-dreaming-20030429gdvm6j.html 
Musharbash, Y. \& Presterudstuen, G. (Eds). (2014). Monster Anthropology in Australasia and Beyond. New York, NY: Palgrave Macmillan. https/doi.org/10.1057/9781137448651 Retrieved from https://www.academia.edu/9601119/Monster_Anthropology_in_Australasia_and_Beyond McCalman, I. (2013). The Reef: A passionate history. Sydney: Penguin/Random House.

Mendelssohn, J. (2013). The 2014 Adelaide Biennial: Contemporary art as it was meant to be. The Conversation, March 4. Retrieved from https://theconversation.com/the-2014-adelaidebiennial-contemporary-art-as-it-was-meant-to-be-23033

Parker, D. (2013). Russell Drysdale, Australian Icon - Tarrawarra Museum of Art, The Cultural Circle, November 4. Retrieved from https://www.thecultureconcept.com/russell-drysdaleaustralian-icon-tarrawarra-museum-of-art

Philp, A. (2017). (Re)claiming Barbara Baynton's Gothic Creek: An Analysis of Gillian Mears' Foals' Bread and Jessie Cole's Deeper Water. eTropic, 16 (2), 107-116. DOI: http://dx.doi.org/10.25120/etropic.16.2.2017.3618. Retrieved from https://journals.jcu.edu.au/etropic/article/view/3618/3486

Power, L. (2015). Weird melancholy: exhibition probes fear at the heart of the Australian landscape, The Sydney Morning Herald, April 3. Retrieved from https://www.smh.com.au/entertainment/weird-melancholy-exhibition-probes-fear-at-theheart-of-the-australian-landscape-20150328-1m9uk2.html

Spicer, C. (2016a). "The Cyclone Which is at the Heart of Things": The Cyclone as Trope of Place and Apocalypse in Queensland Literature. eTropic, 15 (2), 58-67.

DOI: http://dx.doi.org/10.25120/etropic.15.2.2016.3542. Retrieved from https://journals.jcu.edu.au/etropic/article/view/3542/3439

Spicer, C. (2016b). "Big wind, he waiting there": Vance Palmer's Cyclones of Apocalypse and Their Power of Revelation. eTropic, 15 (2), 101-107.

DOI: http://dx.doi.org/10.25120/etropic.15.1.2016.3306. Retrieved from https://journals.jcu.edu.au/etropic/article/view/3306/3251

Spooner, C. (2006). Contemporary Gothic. London, UK: Reaktion Books.

"The Gothic" (2007). Retrieved from https://mitpress.mit.edu/contributors/gilda-williams

Williams, G. (2009). Gothic v Gothick: Gilda Williams on the embarrassing, campy cousin of the uncanny. Art Monthly, 326. Retrieved from https://www.artmonthly.co.uk/magazine/site/issue/may-2009

Wilding, M. (2011). Marcus Clarke's Essential Recycling, Quadrant, November 1. Retrieved from https://quadrant.org.au/magazine/2011/11/marcus-clarke-s-essential-recycling/ 